\title{
Implementasi Nilai-nilai Dasar Pendidikan Agama Kristen di Tengah Pandemi Covid-19 di SMP Abdi Agape Pontianak
}

\author{
Munatar Kause $^{1}$, Supriyanto ${ }^{2}$, Marianus Patora ${ }^{3}$, Desi Arisandi Laga Nguru ${ }^{4}$, Devi Maria Bunga ${ }^{5}$ \\ 1,2,3,4,5Sekolah Tinggi Agama Kristen Teruna Bhakti Yogyakarta \\ 1munatarmoses@gmail.com, 2supriyanto791207@gmail.com,3marianus79patora@gmail.com, \\ 4dessylaganguru3188@gmail.com, 5ibinamhuni@gmail.com
}

\begin{abstract}
This paper discusses the application of Christian Religious Education at SMP Abdi Agape Pontianak in the midst of the Covid-19 Pandemic situation. The impacts of the COvid-19 Pandemic on the world of education which is changing the pattern of education that must go through online learning must not stop the planting of Christian Religious Education in schools. Christian Religious Education must take an important part in instilling the faith and character of Christ in students in the midst of this COVID-19 pandemic.
\end{abstract}

Keywords: Christianit education; covid-19; SMP Abdi Agape

\begin{abstract}
Abstrak: Penelitian ini membahasa mengenai penerapan nilai-nilai dasar Pendidikan Agama Kristen di SMP Abdi Agape Pontianak di tengah-tengah situasi Pandemi COvid-19. Dampak-dampak Pandemi Covid-19 terhadap dunia Pendidikan yang besar yang mengubah pola Pendidikan yang harus melalui pembelajaran online tidak boleh menghentikan penanaman Pendidikan Agama Kristen di sekolah-sekolah. Pendidikan Agama Kristen harus mengambil bagian penting bagi penanaman Iman dan karakter Kristus kepada peserta didik di tengah-tengah pandemic Covid-19 ini.
\end{abstract}

Kata kunci: Covid-19; pendidikan agama Kristen; SMP Abdi Agape

\section{PENDAHULUAN}

Pada saat ini isu-isu yang sangat baru dan masih ada di tengah-tengah masyarakat adalah tentang pandemi Covid-19. Pandemi covid-19 muncul di awal bulan Maret tahun 2020. Pandemi Covid-19 ini memberikan dampak yang sangat luar biasa di semua aspek kehidupan manusia di muka bumi ini. Semua aspek kehidupan manusia berubah secara drastic akibat munculnya pandemi Covid-19 ini. Akibat dari pandemi Covid-19 ini banyak negara yang terpuruk secara. Hal ini di akibatkan lumpuhnya kegiatan ekonomi akibat pembatasan kegiatan sosial masyarakat. Bahkan beberapa negara melakukan Lockdown guna memutus rantai penyebaran Covid-19. Pandemi Covid-19 juga berdampak bagi bangsa Indonesia. Bangsa Indonesia merasakan dampak pandemic ini dari berbagai aspek kehidupan manusia. Secara ekonomi bangsa Indonesia juga mengalami dampak yang luar biasa. Wibowo Hadiwardoyo dalam jurnalnya menulis pembatasan aktivitas akibat pandemi Covid19 telah menimbulkan kerugian ekonomi secara nasional. Kerugian itu hanya akan 
tertutupi apabila krisis dapat diakhiri sebelum menimbulkan kebangkrutan usaha secara massal. ${ }^{1}$

Dunia Pendidikan juga terdampak akibat pandemic Covid-19 ini. Pada masa pendemi ini sekolah-sekolah diwajibkan melakasanakan pembelejaran jarak jauh (PJJ/BDR). Siswa belajar dari rumah secara daring/online. Hal ini memunculkan berbagai masalah dalam pelaksanaan pembelajaran. Masalah pembelajaran online begitu komplek dihadapi baik oleh sekolah maupun oleh peserta didik. Masalahmasalah dari pihak sekolah antara lain; sekolah yang lokasinya tidak ada fasilitas jaringan internet yang tidak memadai.

Pembelajaran jarak jauh/daring membuat disintegrasi di dunia Pendidikan berkenaan dengan Pendidikan karakter siswa. Sekolah sebagai tempat peserta didik belajar baik pengetahuan, keterampilan, sikap dan spiritual tidak sepenuhnya dapat dipenuhi oleh institusi sekolah. Tidak adanya interaksi langsung antara guru dan peserta didik membuat Pendidikan tidak seutuhnya dapat dilaksanakan. Menurut ketentuan Undang-Undang Sisdiknas tersebut, fungsi pendidikan nasional tiada lain adalah mengantarkan generasi muda selaku pihak terdidik agar berkembang kemampuannya serta terbentuk watak dan peradaban bangsa yang bermartabat. Dengan pendidikan nasional, semua anak bangsa Indonesia harus dapat berkembang kemampuan dan karakter atau jati diri serta peradaban bangsanya yang bermartabat. Semuanya itu bermuara pada upaya mencerdaskan kehidupan bangsa, yang merupakan salah satu tujuan berdirinya negara sebagaimana diamanatkan pada alinea keempat. ${ }^{2}$

Dalam kaitannya dengan Penerapan Pendidikan Agama Kristen ditangah Pandemi Covid-19 memiliki tantangan tersendiri, sebab Pendidikan Agama Kristen tidak hanya menekankan tentang teori dan pengetahuan belaka, namun juga berkaitan dengan interaksi sosial antar sesama manusia dalam menerapkan nilainilai Ajaran Kristus dalam kehidupan pribadi maupun juga dalam kehidupan Bersama sebagai sesame manusia yang hidup dalam anugerah Tuhan. Dengan demikian maka perlu adanya terobsan-terobasan baru dalam inovasi penerapan nilai-nilai Pendidikan agama Kristen tetap dapat berjalan sesuai dengan prinsipprinsip dasar pengajaran Yesus.

\section{METODE PENELITIAN}

Dalam Penulisan makalah ini, penulis menggunakan pendekatan metode penelitian deskriptif. Penelitian deskriptif adalah salah satu jenis penelitian yang tujuannya untuk menyajikan gambaran lengkap mengenai setting sosial atau dimaksudkan untuk eksplorasi dan klarifikasi mengenai suatu fenomena atau kenyataan sosial, dengan jalan mendeskripsikan sejumlah variabel yang berkenaan dengan masalah dan unit yang diteliti antara fenomena yang diuji. ${ }^{3}$ Selain metode deskriptif

\footnotetext{
${ }^{1}$ Wibowo Hadiwardoyo, jurnal.umj.ac.id/indeks.php/baskara. 2020

2BuchoryMs et al., "Implementasi Program Pendidikan Karakter Di Smp," Jurnal Pendidikan Karakter, no. 3 (2014): 121995.

${ }^{3}$ https://id.wikipedia.org/wiki/Penelitian_deskriptif, 5 Juli 2010
} 
penulis juga memakai literatur-literatur yang relevan dengan topik yang dibahas. Lokasi penelitian adalah tempat di mana peneliti melakukan penelitian. Menetapkan lokasi penelitian adalah hal yang sangat penting, dengan ditetapkannya lokasi penelitian berarti obyek dan tujuan sudah ditetapkan sehingga mempermudah penulis dalam melakukan penelitian. ${ }^{4}$ Untuk mendapatkan data-data penelitian, peneliti menetapkan SMP Abdi Agape Pontianak sebagai lokasi penelitian. SMP Abdi Agape Pontianak terletak di bagian Utara darikota Pontianak, tepatnya di Jl. Gusti Situtmahmud, Gg. Selat Sumba X, Siantan Tengah, Pontianak Utara. SMP Abdi Agape Pontianak terletak di tengah-tengah perkampungan padat penduduk yang mayoritas adalah suku Tionghoa.

\section{PEMBAHASAN}

\section{Pandemi Covid -19}

Pandemi adalah wabah penyakit yang terjadi secara luas di seluruh dunia. Dengan kata lain, penyakit ini sudah menjadi masalah bersama bagi seluruh warga dunia. ${ }^{5}$ Penyebaran penyakit bisa dikatakan menjadi pandemic apabila sudah menjadi masalah bagi seluruh dunia. Covid-19 adalah penyakit yang disebabkan oleh virus severe acute respiratory syndrome coronavirus 2 (SARS-CoV-2). Covid19 dapat menyebabkan gangguan sistem pernapasan, mulai dari gejala yang ringan seperti flu, hingga infeksi paru-paru, seperti pneumonia. Covid-19 telah menjadi masalah global dunia termasuk di Indonesia. Sampai dengan tanggal 30 Mei 2020, pasien terinfeksi Covid-19 seluruh negara mencapai 6 jutal ebih dengan angka kematian per 1 juta penduduk sebesar 47 orang (Wordometer, 2020). Tabel 1 menyajikan data pasien terinfeksi Covid-19 terbesar di dunia dan Indonesia. Apabila dilihat berdasarkan data tersebut, Indonesia menempati posisi ke-32 dunia untuk total kasus pasien terinfeksi Covid-19. ${ }^{6}$

\section{Dampak Pandemi Covid-19}

Pandemi Covid-19 memiliki dampak yang sangat luas bagi kehidupan manusia di dunia. Segala aspek kehidupan manusia terdampak akan adanya pandemi Covid19 ini. Dampak yang ditimbulkan tidak selalu negative, tetapi juga berdampak positif sebagaian aspek kehidupan manuasia.

\section{Dampak Positif}

Akibat adanya pandemi Covid-19 berdampak pada semakin berkembangnya dunia IT. Sekolah jarak jauh/daring menuntut guru untuk menguasai dunia digital/IT. Guru dituntut untuk membuat bahan ajar yang menarik dan kreatif agar bisa diterima peserta didik dengan baik dan tidak membosankan. Setiap sistem sekolah harus moderat dengan teknologi yang memungkinkan mereka belajar lebih cepat, lebih baik, dan lebih pintar. Dan Teknologi Informasi adalah kunci untuk model sekolah masa depan yang lebih baik. Namun upaya anak-anak bangsa juga

\footnotetext{
${ }^{4}$ http://etheses.uin-malang.ac.id/711/7/09510127\%20Bab\%203.pdf 2020

${ }^{5}$ https://www.alodokter.com/memahami-epidemiologi-dan-istilah-istilahnya/10Agustus

6 Dani Sugiri., "Menyelamatkan Usaha Mikro, Kecil dan Menengah dari Dampak Pandemi Covid-19" 19, no. 1 (2020): 76-86.
} 
terus dilakukan untuk mengejar ketertinggalan bangsa Indonesia dalam hal menyampaikan proses pendidikan dengan menggunakan IT. ${ }^{7}$ Karena sifat internet yang dapat dihubungi kapan saja, itu berarti siswa dapat memanfaatkan program pendidikan yang disediakan di internet kapan saja sesuai dengan waktu luang mereka, sehingga ruang dan kendala waktu yang mereka hadapi dalam menemukan sumber belajar dapat diatasi. ${ }^{8}$ yang terhubung ke internet sebagai media utama telah mampu memberikan kontribusi yang begitu besar bagi proses pendidikan. Teknologi interaktif ini menyediakan dorongan untuk transformasi pasar menuju peran guru: dari informasi menjadi transformasi. ${ }^{9}$

\section{Dampak Negatif}

Pandemi COVID-19 adalah krisis kesehatan yang pertama dan terutama di dunia. Banyak negara memutuskan untuk menutup sekolah, perguruan tinggi dan universitas. Perserikatan Bangsa-Bangsa (PBB) menjadi gusar dengan adanya fakta tersebut. Organisasi Internasional yang bermarkas di New York, AS, itu menangkap bahwa pendidikan menjadi salah satu sektor yang begitu terdampak oleh virus corona. Parahnya lagi, hal itu terjadi dalam tempo yang cepat dan skala yang luas. Berdasarkan laporan ABC News 7 Maret 2020, penutupan sekolah terjadi di lebih dari puluhan negara karena wabah COVID-19. Menurut data Organisasi Pendidikan, Keilmuan, dan Kebudayaan PBB (UNESCO), setidaknya ada 290,5 juta siswa di seluruh dunia yang aktivitas belajar nya menjadi terganggu akibat sekolah yang ditutup. ${ }^{10}$ Dampak Pandemi Covid-19 terhadap Pendidikan juga terasa di Indonesia, banyak sekolah-sekolah ditutup dan memaksa peserta didik belajar di rumah (PJJ).

Selain dunia Pendidikan, bangsa Indonesia adalah salah satu negara yang terdampak terutama pada sisi ekonomi (Pakpahan, 2020). Pandemi Covid-2019 membawa berbagai dampak pada perekonomian seperti terjadi kesusahan dalam mencari lapangan pekerjaan, susah untuk memenuhi kebutuhan hidup sehari-hari, tidak mempunyai penghasilan dalam memenuhi kebutuhan untuk sehari-hari dan juga banyak kesusahan yang di terima dari semua sector perekonomian dalam semua bidang juga merasakan dampak dari Covid-19 (Hanoatubun, 2020). ${ }^{11}$ Pada saat ini disrupsi teknologi terjadi di dunia Pendidikan, pembelajaran tatap muka yang dilaksanakan 100 persen di sekolah, secara tiba-tiba mengalami perubahan yang sangat drastic. ${ }^{12}$ Pembelajaran jarak jauh/daring membuat disintegrasi di dunia Pendidikan berkenaan dengan Pendidikan karakter siswa. Sekolah sebagai

${ }^{7}$ Yulita Pujilestari, "Dampak Positif Pembelajaran Online Dalam Sistem Pendidikan Indonesia Pasca Pandemi Covid-19," Adalah 4, no. 1 (2020): 49-56,

http://journal.uinjkt.ac.id/index.php/adalah/article/view/15394/7199.

8 Ibid.

${ }^{9}$ Ibid.

${ }^{10}$ Agus Purwanto et al., "Studi Eksploratif Dampak Pandemi COVID-19 Terhadap Proses Pembelajaran Online di Sekolah Dasar," EduPsyCouns: Journal of Education, Psychology and Counseling 2, no. 1 (2020): 1-12, https://ummaspul.e-journal.id/Edupsycouns/article/view/397.

${ }^{11}$ Dani Sugiri Mikro et al., "Menyelamatkan Usaha Mikro, Kecil dan Menengah dari Dampak Pandemi Covid-19."

12Matdio Siahaan, "Dampak Pandemi Covid-19 Terhadap Dunia Pendidikan," Jurnal Kajian Ilmiah 1, no. 1 (2020): 73-80. 
tempat peserta didik belajar baik pengetahuan, keterampilan, sikap dan spiritual tidak sepenuhnya dapat dipenuhi oleh institusi sekolah. Tidak adanya interaksi langsung antara guru dan peserta didik membuat Pendidikan tidak seutuhnya dapat dilaksanakan

\section{Pendidikan Kristen}

Pendidikan Kristen adalah sebuah tugas ilahi. Keunikannya melampui batas humanitas karena aspek subject matter, goal, dan spiritual dynamic yang tercakup di dalamnya. Di Indonesia sejarah membuktikan bahwa melalui pendidikan Kristen tepatnya pendidikan agama Kristen Allah dengan kedaulatan-Nya beranugerah atas bangsa ini sehingga Injil dapat dikabarkan secara sistematis kehampir seluruh nusantara. Allah memakai legalitas pemerintah untuk menjadikan pendidikan Kristen sebagai mata pelajaran wajib di bangku pendidikan. Artikel ini akan memaparkan secara singkat sejarah, makna dan tugas pendidikan Kristen dalam memuridkan jiwa sesuai dengan Amanat Agung. ${ }^{13}$

\section{Penanaman Iman Kepada Peserta Didik}

Pendidikan Kristen adalah suatu pengajaran dengan tujuan memberitakan Injil Allah atau karya keselamatan Allah kepada umat-Nya yang berdosa dan penanaman iman kepada Tuhan Yesus sebagai Tuhan dan juruselamatnya yang telah mati di kayu salib untuk menebus dosa-dosa manusia. Dalam Kitab Matius 28: 18-20 yang biasa disebut "Amanat Agung" jelas di dalamnya terkandung perintah Tuhan Yesus untuk mengajar dan menjadikan semua bangsa murid-Nya. Hal ini menjadi dasar Pendidikan Kristen agar terus berkembang dan maju dari masa ke masa. Amanat agung merupakan bagian penting dalam kehidupan kekristenan atau gereja. Salah satu factor pertumbuhan gereja (secara kuantitatif) adalah dengan melaksanakan amanat agung. Gereja yang melaksanakan amanat agung merupakan gereja yang dinamis, terus bertumbuh dan berkembang. Selain itu, amanat agung merupakan hakikat dari tugas dan panggilan gereja dalam dunia yang tidak boleh diabaikan. Ini merupakan tugas yang tidak dapat ditolak oleh semua orang Kristen, karena sesuai dengan sifatnya, yakni sebuah amanat yang datangnya dari Yesus. ${ }^{14}$ Dalam situasi dan keadaan apapun Pendidikan Kristen harus tetap dijalankan sebagai bagian dari ketaatan kepada perintah Tuhan melalui Amanat Agung.

Penanaman iman kepada peserta didik melalui Pendidikan Kristen merupakan bagian dari pelaksanaan Amanat Agung Tuhan Yesus. Amanat Agung bukan hanya sekedar pergi dan menginjil, lebih dari itu, Amanat Agung adalah perintah untuk mengajar dan memuridkan segala bangsa, yang dapat diartikan memuridkan peserta didik untuk menjadi murid-murid TuhanYesus. Sebagai seorang pendidik Kristen di tengah pandemi yang mengharuskan sekolah secara daring/online, pendidik dituntut untuk lebih kreatif dan inovatif agar peserta didik tetap menda-

13 Oda Judithia Widianing, "Pendidikan Kristen di Sekolah: Sebuah Tugas Ilahi Dalam Memuridkan Jiwa," Jurnal Teologi Berita Hidup 1, no. 1 (2018): 78-89.

${ }^{14}$ Handreas Hartono, "Mengaktualisasikan Amanat Agung Matius28: 19-20 dalam Konteks Era Digital," KURIOS (Jurnal Teologi dan Pendidikan Agama Kristen) 4, no. 2 (2018): 19-20, www.sttpb.ac.id/e-journal/index.php/kurios. 
patkan pengajaran dan Pendidikan yang utuh. Utuh dalam artian secara pengetahuan, sikap dan spiritualitasnya. Dr. Howard G Hendricks dalam bukunya Mengajar Untuk mengubah Hidup menulis bahwa pengajar yang efektif selalu mengajar dari limpahan hidupnya yang penuh. Hukum pengajar secara sederhana adalah jika anda berhenti bertumbuh hari ini, anda akan berhenti mengajar dikemudian hari. ${ }^{15}$ Meskipun belajar secara daring/online seorang pendidik dituntut tetap harus mengajar sepenuh hati untuk penenaman iman kepada peserta didik.

\section{Penanaman Karakter Kristus Kepada Peserta Didik}

Meresponi pemerosotan budi pekerti manusia secara global dan lokal, pentingnya pendidikan karakter di sekolah sudah ditekankan oleh pemerintah sejak tahun 2010 yang lalu. Hal tersebut ditegaskan dalam Peraturan Pemerintah R.I Nomor 17 Tahun 2010 Tentang Pengelolaan dan Penyelanggaraan Pendidikan, Bab III, tentang fungsi dan tujuan pendidikan anak usia dini; pendidikan dasar; pendidikan menengah; dan pendidikan tinggi. Perkara itu kemudian dijabarkan oleh Kebijakan Nasional Pembangunan Karakter Bangsa Tahun 2010-2025 (Pemerintah RI, 2010), Bahan Pelatihan Pengembangan Pendidikan Budaya dan Karakter Bangsa (Kementerian Pendidikan Nasional (2010) dan Pedoman Pelaksaan Pendidikan Karakter (Kementerian Pendidikan Nasional, 2011). ${ }^{16}$ Abd. Kadim Masaong, menjelaskan bahwa karakter dapat diartikan sebagai sifat pribadi yang relative stabil pada diri individu yang menjadi landasan penampilan perilaku dalam standar nilai dan norma yang tinggi. Karakter merupakan sikap dan kepribadian seseorang yang diyakini nya baik dan berwujud dalam tingkah lakunya sebagai pribadi yang menjadikannya mempunyai reputasi sebagai orang baik Karakter dapat diartikan sebagaisifat pribadi yang relative stabil pada diri individu yang menjadi landasan penampilan perilaku dalam standar nilai dan norma yang tinggi. Karakter merupakan sikap dan kepribadian seseorang yang diyakini nya baik dan berwujud dalam tingkah lakunya sebagai pribadi yang menjadikannya mempunyai reputasi sebagai orang baik. ${ }^{17}$

Menurut David Eko Setiawan, Pendidikan karakter unggul adalah usaha sadar dan terencana dengan tujuan menginternalisasikan nilai moral dan akhlak, sehingga hal itu dapat diwujudkan dalam penerapan sikap dan perilaku yang baik. Untuk mencapai tujuan tersebut maka perlu dipikirkan sebuah peristiwa terpenting yang harus terjadi dalam kehidupan manusia. ${ }^{18}$ Penanaman Karakter Kristus yang mencerminkan Karakter Kristus kepada peserta didik adalah tanggungjawab yang besar yang diemban oleh sekolah. Sekolah harus berupaya keras guna menanamkan 2016), 19

${ }^{15}$ Dr. Howard G Hendricks, Mengajar Untuk Mengubah Hidup(Yogyakarta: Yayasan Gloria,

16Binsen S Sidjabat, "Penguatan Guru Pak Untuk Pendidikan Karakter :," Evangelikal: Jurnal Teologi Injili dan Pembinaan Warga Jemaat 3 (2019): 30-48.

17 Prof Abd, Kadim Masaong, dan M Pd, “Pendidikan Karakter Berbasis Multiple Intelligence," Konaspi VII, no. 5 (2012): 1-10.

18 David Eko Setiawan, "Kelahiran Baru Di Dalam Kristus Sebagai Titik Awal Pendidikan Karakter Unggul," Evangelikal: Jurnal Teologi Injili dan Pembinaan Warga Jemaat 3, no. 2 (2019): 154. 
karakter Kristen kepada peserta didik melalui Pendidikan Agam Kristen di sekolah. Sekolah-Sekolah Kristen harus bisa menghasilkan output yang memiliki karakter Kristen yang bisa menjadi garam dan terang dunia. Di tengah-tengah Pandemi Covid-19 yang mana membuat sekolah-sekolah melaksanakan Pembelajaran Jarak Jauh (PJJ) atau secara Online sedikit banyak menghambat bagi penanaman karakter Kristus kepada peserta didik. Namun demikian, sekolah-sekolah, terutama sekolah Kristen harus tetap berupaya untuk menanamkan kareakter kristus kepada peserta didiknya. Situasi Pandemi Covid-19 ini dapat digunakan untuk menanamkan karakter-karakter kepada peserta didik agar mereka memiliki kesabaran, ketabahan dan iman yang sungguh-sungguh serta berpengharapan kepada Yesus di tengahtengah situasi Pandemi Covid-19 ini.

SMP Abdi Agape Pontianak, tetap dalam konsentrasi penuh untuk menerapkan Nilai-nilai Kekristenan walaupun ditengah Pandemi Covid-19. Walau-pun seperti yang telah diuraikan diatas bahwa ada dampak negaitif, namun bukanlah menjadi dasar untuk tidak menekankan nilai-nilai dasar kehidupan Kris-tiani. Siswa-siswa SMP Abdi Agape dalam konsentasi penuh untuk menerapkan nilai-nilai tersebut, sebab dalam situasi seperti ini akan teruji sejauh mana setiap siswa apakah mampu untuk menerapkan nilai kehidupan kristiani bagi diri sendiri dalam hal Iman dan juga bagi orang lain untuk menjadi saksi dalam kepedulian terhadap sesame.

\section{KESIMPULAN}

Berasarkan pemaparan diatas yang berhubungan dengan penerapan Pendidikan Agama Kristen di tengah Pandemi Covid-19 di SMP Abdi Agape Pontianak sudah berjalan cukup baik melalui metode-metode pembelajaran yang menekankan kepada keterampilan siswa di dalam menyikapi situasi Pandemi Covid-19 yang melanda bangsa Indonesia saat ini. Secara keseluruhan penerapan Pendidikan Agama Kristen di SMP Abdi Agape Pontianak di tengah situasi pandemic Covid-19 masih perlu untuk ditingkatkan Kembali dengan mencari metode atau strategi pembelajaran yang tepat dengan memaksimalkan peran guru PAK serta media-media pembelajaran yang ada.

Dari kesimpulan di atas yang sudah dijabarkan oleh peneliti dapat diusulkan gagasan-gagasan baru atau saran-saran yang dapat meningktkan peran Pendidikan Agama Kristen bagi penanaman iman dan karakter kristus kepada peserta didik: Penggunaan teknologi sebagai media pembelajaran, Penggunaan teknologi sebagai media komunikasi baik secara kelompok atau pribadi dengan peserta didik dalam konteks sharing, Mendorong peserta didik untuk rajin kegereja. Hal lain yang dapat ditawarkan dalam penelitian ini adalah bagaimana penekanan tentang eksistensi nilai-nilai Kekristenan walaupun dalam situasi pandemic Covid-19, dan tentunya dalam semuanya itu memerlukan terobosan-terobasan baru atau kreatifitas seorang tenaga pendidik Pendidikan Agama Kristen diperlukan. 


\section{REFERENSI}

Hendricks, Howard G Mengajar Untuk Mengubah Hidup (Yogyakarta: Yayasan Gloria, 2016),

Hadiwardoyo, Wibowo. Jurnal.umj.ac.id/indeks.php/baskara. 2020https://id.wikipedia.org/wiki/Penelitian_deskriptif, 5 Juli 2010

http://etheses.uin-malang.ac.id/711/7/09510127\%20Bab\%203.pdf

https://masyarakatbelajar.wordpress.com/2009/08/23/kehadiran-peneliti-dalampenelitian-kualitatif/

https://www.alodokter.com/memahami-epidemiologi-dan-istilah-istilahnya/10, Agustus 2020

Masaong, Abd. Kadim. "Pendidikan Karakter Berbasis Multiple Intelligence," Konaspi VII, no. 5 (2012):

Pujilestari, Yulita. "Dampak Positif Pembelajaran Online Dalam Sistem Pendidikan Indonesia Pasca Pandemi Covid-19," Adalah 4, no. 1 (2020)

Purwanto, Agus et al., "Studi Eksploratif Dampak Pandemi COVID-19 Terhadap Proses Pembelajaran Online di Sekolah Dasar," Edu Psy Couns: Journal of Education, Psychology and Counseling 2, no. 1 (2020):

Setiawan, David Eko. "Kelahiran Baru Di Dalam Kristus Sebagai Titik Awal Pendidikan Karakter Unggul," Evangelikal: Jurnal Teologi Injili dan Pembinaan Warga Jemaat 3, no. 2 (2019):https://www.quipper.com/id/blog/tipstrick/school-life/penelitiandeskriptif/\#Pengertian_Penelitian_Deskriptif, 8 Juli 2020

Siahaan, Matdio. "Dampak Pandemi Covid-19 Terhadap Dunia Pendidikan," Jurnal Kajian Ilmiah 1, no. 1 (2020):

Sidjabat, Binsen S. “Penguatan Guru Pak Untuk Pendidikan Karakter,” Evangelikal: Jurnal Teologi Injili dan Pembinaan Warga Jemaat 3 (2019):

Sugiri, Dani. "Menyelamatkan Usaha Mikro, Kecil dan Menengah dari Dampak Pandemi Covid-19" 19, no. 1 (2020).

Widianing, Oda Judithia. "Pendidikan Kristen di Sekolah: Sebuah Tugas Ilahi Dalam Memuridkan Jiwa," Jurnal Teologi Berita Hidup 1, no. 1 (2018): 